\section{An empirical assessment of Islamic leadership principles}

Islamic
eadership
principles

\author{
Khaliq Ahmad
}

Kulliyyah of Economics and Management Sciences, International Islamic University Malaysia, Kuala Lumpur, Malaysia, and

Ogunsola O.K.

Graduate School of Management,

Kulliyyah of Economics and Management Sciences,

International Islamic University Malaysia, Kuala Lumpur, Malaysia

\begin{abstract}
Purpose - The main purpose of the present paper is to document some Islamic leadership principles of management. The paper equally examines the leadership function as adopted by academic administrators within the International Islamic University, Malaysia vis-à-vis Islamic principles of management. The whole process is an attempt to conduct an empirical study of the important role of excellent leadership from an Islamic perspective.

Design/methodology/approach - A combination of revealed sources of knowledge (the Quran and Sunnah) and literature reviews were used to document Islamic leadership principles. Then, a questionnaire-based survey was used to examine the Islamic leadership principles, approaches, and sources of leadership principles adopted in the university. Use of the scale of statistical measurement was done to test the significance and reliability level.

Findings - It was found that academic administrators were imbued with Islamic leadership principles. The research also showed that servant-leadership approach is preferably used in conjunction with alternative transactional and transformational styles, while the revealed sources of knowledge (Quran and Sunnah) were given the highest priority as sources of developing leadership principles.

Research limitations/implications - Islamic management is a diverse field. This study is, however, limited to Islamic leadership principles in an organization. Perhaps, this study will be little known to adherents of the conventional management principles, which may stimulate further thinking and debate on the crossing point between Islam and the management of an organization.

Originality/value - It is aimed at providing some knowledge of Islamic philosophy and practice in order to help today's employers and employees carry on everyday activities imbued with Islamic values and cultures.
\end{abstract}

Keywords Islamic leadership principles, Leadership approaches, Islamic perspectives, Islamic management, Universities, Leadership, Islam, Malaysia

Paper type Research paper

\section{Introduction}

The population of Muslims in the world is growing, ranging from the Middle East down through Africa, out through Southeast Asia and Australia, up through China and the Soviet Union, and into parts of Europe, including both North and South America. It is a community that shares a substantial common faith, behavior, and cultural heritage. Thus, managing in the diverse global environment often means being more sensitive towards time, distance, cultural, social, religious, language, and civilization differences, which is no simple task (Khaliq, 2009). 
IJCOMA

21,3

292
Many authors have explored the relation between management theory and religion. The possibility that alternative religious and cultural traditions might produce quite different patterns of organization and management style have been noted. Both at managerial and non-managerial levels and often trained in Western business schools, many Muslims still find orientation more in the Western concept of management. To them religion is a private matter, hence to be separated from public domain of an organization, which is a conviction against that of the revealed sources of knowledge. There arises a need for an alternative and more comprehensive management theory that will survive the test of commonality and reality. This is known as management from an Islamic perspective (MIP), it encompasses visionary leadership, strategic management thinking, management of change, fair treatment and social justice among employees, sincerity and commitment, and motivational issues (Khaliq, 2003). Under the Islamic theory of management, both an individual Islamic beliefs as well as organizational management operates under the same revealed rules and directives and shariah compliance is necessary.

Islamic management deals with management of organizations from the perspective of the knowledge acquired from revealed and other Islamic sources of knowledge and results in applications compatible with the Islamic beliefs and practices (Kazmi, 2007). Arsyianti and Beik (2007) consider both "Itqan" and "Ihsan" as departure points of management concept and considered fundamentals in forming and defining MIP. They write that Islam is a comprehensive religion that unites all aspects of followers' live here and in the hereafter. That is, Islam does not differentiate between temporal, i.e. secular aspects of life and religious aspects of life. Hence, it becomes a unifying divine doctrine in which leaving out any part of it negates the whole system of Tawheedic paradigm.

\section{Definitions of terms}

- Leadership approach. This includes all practices, traits, behaviors, processes, roles, and styles that leaders have and do to lead the followers, emphasizing the importance of the situational factors.

- Power-influence leadership approach. A leadership approach that views power and influence as a key to the role of leadership (Dewi and Tanjung, 2007).

- Servant-leader approach. This is a moral leadership approach that leans toward values, ethics, principles, virtues, morality, spirituality, and authenticity. It advocates that leaders should serve those under them, helping them to reach maximum effectiveness (Beekun, 2006; Khaliq, 2009).

- Transactional and transformational leadership approaches. Transactional leadership is a moral leadership approach and an exchange of rewards with subordinates for services rendered. Transformational leadership approach leads the change in the organization's vision, strategy, and culture, and it empowers people in the organization and increases the base of power and effectiveness rather than restricting it (James and Joseph, 2001; Muenjohn, 2008).

- Trait approach. It is a leadership approach that assumes that leaders and leadership demonstrate certain traits and that a leader has superior endowed qualities and behavioral attributes (Adnan, 2006; Beekun and Badawi, 1999). 
- Situational leadership approach. It is one of the various studies of the contingency research, and it is based on the relationship between the leader and followers and the importance of the situation in the leadership process (Adnan, 2006).

- Islamic leadership principles. A group of leadership principles that were extracted primarily from the Qur'an and the biography of the Prophet Muhammad and his companions for the orientation of governmental affairs and the construction of good and ethical leadership to guide the Islamic leaders in running Islamic organizations appropriately and effectively. It draws upon the noblest Islamic traditions of science, worship, justice, and Ihsan (doing good), and seeks to inculcate these values in Muslims (Khaliq, 2009; Khan, 2007).

- Leadership sources. It includes Qur'anic scriptures, Prophet Muhammad's (SAW) sayings and actions as well as those of the four caliphs (Adnan, 2006; Al-Buraey, 2006; Beekun, 2006; Khaliq, 2009).

\section{Literature review}

As with conventional practices, leadership in Islam also serves as a bridge used by leaders to influence their members' attitude and behaviors to achieving organizational objectives (Adlouni and Sweidan, as cited in Ali, 2007). It is the ability to see beyond assumed boundaries and to come up with solutions or paths that few can visualize (Murad, as cited in Beekun and Badawi, 1999). The leader must be a visionary leader to lead an organization into success (Khaliq, 2009). The Qur'an is a continuing source of guidance, and the guidance it offers is in the context of what the reader is seeking. Learning from the Qur'an is a dynamic process and that is why we keep reading it in all sorts of circumstances and needs. Why look for lessons in leadership? Because all of us as Muslims and Muslimahs, must play a leadership role as enshrined by the almighty in one setting or another. One of the well-known Hadiths of the Prophet (SAW) was:

"Kullu kum ra'in wa' kullu ra'in mas'ool an rai'yatay-hi [. . .]" meaning that "Every one of you is a caretaker, and every caretaker is responsible for what he is caretaker of" (Sahih Muslim).

\section{Leadership and Islam}

Leadership in Islam is similar to conventional leadership except in its religious, moral, and human roots. Religious and moral spirit (fear of God) dominated leadership during the Prophet's (SAW) and the Four caliphs' reign (Al-Buraey, 2006). From an Islamic perspective, the Islamic roots of leadership generally exist in the primary sources of Shariah (Qur'an and Sunnah) in addition to the practices of the early Muslims. Complementarily, there is also a strand in conventional leadership thought that stresses the importance of spirituality, religious values, and human relationships. In essence, leadership is about offering oneself and one's spirit (Greenleaf as cited in Beekun and Badawi, 1999). It is believed that leadership fails when people have overemphasized bureaucratic, psychological, and technical-rational authority and have neglected professional, moral as well as spiritual authority:

In our lifetime, individualism has been so strong that we may not yet have had the occasion to consider radically the notion of a truly common life. It wouldn't take much to conceive business as an enterprise in service of families and communities. It wouldn't take much imagination to connect work with individual calling and oriented towards the real needs of a community. Then we might discover to our surprise that money, business, commerce, and industry can all be part of our work of the soul (Thomas Moore). 
IJCOMA

21,3

294
Rost (as cited in Beekun, 2006) viewed leadership as a dynamic relationship based on mutual influence and common purpose between leaders and followers in which both are moved to higher levels of motivation and moral development as they affect real intended change. In fact, Islam demands that leaders pay attention to followers' needs. It is trusteeship of Allah, a responsibility given from him and a service to mankind (Toor, 2007):

If Allah puts anyone in the position of authority over the Muslims' affairs and he secludes himself (from them), not fulfilling their needs, wants, and poverty, Allah will keep Himself away from him, not fulfilling his need, want, and poverty (Sahih Muslim).

Concurrently, followers must provide leaders with sincere and impartial feedback. They should support and help their leaders towards good acts. Umar (RA) said: "May God have mercy upon anyone who points out my faults to me". The followers are also obliged to follow their leaders' directives as long as the leaders act according to commands of the Islamic revealed sources of knowledge. Leadership is a crucial concept because Muslims known for their collectivism are urged, in most circumstances in life, to appoint someone as a leader.

Management activities such as planning, organizing, and controlling could be dormant cocoons until the leader triggers the power of motivation in people and guides them towards their goals (Khaliq, 2003). This is a philosophy reflected in Muslims being Allah's vice-regents on earth. The appointment of a leader then becomes imperative for Muslims in different walks of life and as Allah's vice-regents, they are gifted with the cognitive ability and qualities which if properly deployed could result in the achievement of the greatest objective (Allah's pleasure) both in everyday life and the hereafter. Khaliq (2009) referred to this achievement as Falah (true success) in his study of "Leadership and work motivation from the cross-cultural perspective".

In Islam, leadership is a process of inspiring and coaching voluntary followers in an effort to achieve a clear and defined shared vision (Adnan, 2006). It is seen as human factors that bind a group together and motivate it toward desired goals (Beekun and Badawi, 1999). Hence, in Islam, a leader is not free to act as he or she chooses, nor must he submit to the wishes of any group, he or she must act only to implement Allah's laws on earth. Allah says:

And We made them leaders guiding men by Our command and We sent inspiration to do good deeds, to establish regular prayers, and to practice regular charity; and they constantly served Us only (Surah Al-Anbiya', [21] 73).

Leadership in Islam centers on trust (Amaanah). It represents a psychological contract between leaders and their followers that they will try their best to guide, protect, and treat their followers justly (Khaliq, 2007a, b). It revolves on doing good deeds for the sake of Allah, the Muslim community and humankind. Al-Buraey (as cited in Ali, 2007) stated that Islamic leadership assists the individual in attaining happiness in both worlds.

\section{Islamic leadership principles}

Islamic leadership deals with management of organizations from the perspective of the knowledge acquired from revealed and other Islamic sources of knowledge and results in applications compatible with Islamic beliefs and practices (Kazmi, 2007). It is a concept whose principles are derived from the doctrine of Tawheed as practiced by the Prophet (SAW) (Khaliq, 2007a, b). Allah says in the Quran: 
He, it is Who has sent the Prophet (SAW) with guidance and the Deen of Truth so that it may become dominate over all other systems, however much of the mushrikeen may be averse to it (Surah At-Taubah, [9] 33 and Surah As-Saff, [61] 9).

Khan (1998) reiterated that human beings have been ordained with great faculties and qualities which if properly deployed could result in the achievement of miraculous goals. Reaching these goals necessitates the application of certain Islamic principles or tools. Hossain (2007) wrote that these principles are not "new" in the sense of being completely new, but rather they represent a fresh application of certain basic assumptions that might not have been thought of as having an action element. This implies the reawakening of our thoughts and consciences towards the revealed sources of knowledge (Qur'an and Sunnah). These principles promote the culture of God-consciousness and justice within the organization while guarding against tyranny and oppression (Khaliq, 2009).

The list of Islamic leadership principles compiled by Muslim authors are endless; for instance, in an article written by Khan (1998), some Islamic leadership principles practiced by the Prophet (SAW) were mentioned as follows: begin from the possible, see advantage in disadvantage, change the place of action, make a friend out of an enemy, turn minus into plus, the power of peace is stronger than the power of violence, not to be a dichotomous thinker, to bring the battle in one's own favorable field, gradualism instead of radicalism, and to be pragmatic in controversial matters.

Kassem and Al-Buraey (as cited in Ismail, 2007) gave instances of leadership principles in Islam. They discoursed that team-building techniques could be seen in Friday (Juma'at) sermons, congregational prayer, and zikr circles. Khan (1998) wrote that the Prophet of Islam (SAW) was a positive thinker and his activities were always result oriented by completely refraining from all such steps as may prove counter productive. Khaliq (2007a, b) equally wrote on some leadership qualities that were exemplified by the Prophet (SAW). They include: patience (Sabr), eloquence (Fasah), enterprise (Iqdam) and leniency (Lin). According to Ismail (2007), he emphasized two principles practiced by the Prophet (SAW) namely, receiving the message; a principle likened to the act of seeking guidance and knowledge in order to direct the affairs to the followers. Also, spreading the message; referring to the act of delegating tasks and ensuring that they are well accomplished.

Khan (2007) grouped the following as cardinal Islamic leadership principles and values; faith and belief, knowledge and wisdom, courage and determination, mutual consultation and unity (fraternity and brotherhood), morality and piety (honesty and trust), superior communication, justice and compassion, patience and endurance, commitment and sacrifice, lifelong endeavour, and gratitude and prayers. In the work of Adnan (2006), he identified ten personal qualities of a Muslim leader, namely, conviction (yaqin), mutual consultation (shura), knowledge (ma'refah), justice ('adl), self-sacrifice (tadhyah), humility, eloquence (fasah), patience (sabr), leniency (lin), and enterprise (iqdam). Lukman (1995) in his study also identified six general principles: sovereignty (Al-Siyadah), mutual consultation (Al-shura), justice (Al-'Adalah), equality (Al-Musawat), freedom (Al-Hurriyyah) and enjoining the right and forbidding the evil. He regarded them as the modern terminology involved in setting up an Islamic organization.

Based on the above-reviewed literatures, the researcher developed and tested the following Islamic leadership principles through a questionnaire-based survey;
Islamic
leadership
principles

295 
IJCOMA

21,3

296 faith and belief in God, knowledge and wisdom, courage and determination, mutual consultation, morality and piety, patience, express gratitude, and endurance. They were considered the principles through which the Prophet of Islam (SAW) gained success and they have been recognized by scholars of Islam as the true principles to achieve Falah - true success. Leaders are enjoined to embrace these principles as their application will not only earn them the blessings of Allah but will also offer them an opportunity to fulfil their duties towards their followers and the society at large. The researcher equally assessed three leadership approaches of the university academic administrators. They were transformational, transactional, and servant-leadership approaches.

\section{Research questions}

Guided by the purpose of the study, the research questions underlying the investigation in this study are as follows:

$R Q 1$. Which leadership approach is used within the organizational structure of International Islamic University Malaysia?

$R Q 2$. To what sources do the university administrative staff attribute their use of the leadership or followership principles?

RQ3. To what degree has Islam influenced the use of leadership or followership principles?

\section{Methodology}

From an Islamic perspective, research methodology is the study of principles and guidelines that regulate the acquisition of knowledge and it involves the acceptance or rejection of proposition as part of the body of knowledge in a particular field (Faridi, 1991). Research design is the framework for controlling the collection of the required data accurately and economically (Uma and Bougie, 2003). It is used for the purpose of obtaining data needed to test hypothesis or answer research questions (Sanders and Pinhey, 1983).

\section{Research design}

In this study, there were two sections of the questionnaire. Section A pertains to the respondents' demographic information such as age, sex, educational background, nationality, marital status, religion, and working experience. Section B consists of seven parts of the questionnaire. In this section, all questions were evaluated based on a five-point Likert scale except the last question which was open-ended. This open-ended question was given to the respondents for their suggestions about leadership improvement in the workplace.

\section{Data collection}

Both primary and secondary data collection methods were employed. For secondary data: articles, journals, and information from various national and international publications on Islamic management and related topics were used. The primary data was gathered through a questionnaire-based survey to profile the university. Irrelevant questions were scrutinized and avoided following the review of relevant literatures on the study. The development of the research questionnaire was based on a review 
of literature encompassing principles, approaches, traits, roles, and practices of leadership in Islam (Adnan, 2006; Beekun, 2006; Khaliq, 2007a, b). Questions were asked on a five-point Likert scale. Scaling is the term applied and used in the measurement of human responses to stimuli (Emory, 1985). Composite scales of five or more points help in defining more accurately, gradations of intensity and information on several dimensions of the stimulus or response (Simon, 2003). Questionnaires were designed to fit electronic tabulation through the use of Statistical Package for the Social Sciences (SPSS) Version 17.0 software.

A total numbers of 300 questionnaires were sent out to middle- and first-line administrative staff in the university to gather quantitative data. The selected sample represents approximately 25 percent of the entire university administrative staffs. From the 300 questionnaires, the researcher was able to get 277 questionnaires back out of which six were unusable due to incomplete information. The researcher was left with only 271 questionnaires representing approximately 90 percent of the targeted sampling. The rationale behind choosing this sampling was based on the vision and mission statement of the university. The university's mission is described as integration, Islamization, internationalization, and comprehensive excellence (III and $\mathrm{CE}$ ). Thus, the researcher considered the university to be a large employer of Muslim workers likely imbued with Islamic principles and a good example of a visible field of study. Respondents were only middle- and first-line administrative staffs who were asked to assess their supervisors, team leaders, coaches, or other persons, to whom they are accountable, most of whom are academic administrators of IIUM.

\section{Data analysis}

Respondents' demographics are tabulated as below. Table I gives details of the respondents participating in the administration of the questionnaire.

The low percentage of $\mathrm{PhD}$ staff as shown in Table I was because only middle- and first-line members of administrative staff were target respondents who most often than not are not required to have a $\mathrm{PhD}$-level education. The university has quite large a number of $\mathrm{PhD}$ staff within academia, but a few only holding administrative positions.

\section{Reliability analysis}

According to Malhotra and Birks (1999, p. 313), reliability refers to the extent to which measurements of the particular test are repeatable. This means that the outcomes of the measurement, in repeated sequences of measuring, must be consistent. The greater the level of consistency in repeated sequences in which we assess measures, the greater the reliability.

The value range of this coefficient is between 0 and; accordingly the value of the coefficient closer to 1 would indicate the greater reliability. In this study, Cronbach's $\alpha$ coefficients are used to examine the internal consistency of the items, and items with adequate Cronbach's $\alpha$ are retained for the scales. The values of the coefficients are calculated by using SPSS reliability procedure and these are presented in Table II.

The value of Cronbach's $\alpha$ for "Islamic leadership principles" is calculated as a score of 0.907 , which was above the traditional acceptable value of 0.70 . All constructs meet the recommended cut-off value (0.70). Therefore, all of the constructs of Islamic leadership principles are acceptable and a total of 68 items are retained for the eight

\section{Islamic leadership principles}

297 


\section{IJCOMA \\ 21,3}

298

Table I.

Demography of respondents

\begin{tabular}{|c|c|c|c|c|}
\hline & & & & \\
\hline & & & & \\
\hline & Count & $\%$ & Count & $\%$ \\
\hline Age & & & & \\
\hline $20-25$ & 11 & 34.4 & 21 & 65.6 \\
\hline $26-30$ & 22 & 19.8 & 89 & 80.2 \\
\hline $31-35$ & 25 & 32.5 & 52 & 67.5 \\
\hline Over 35 & 26 & 51.0 & 25 & 49.0 \\
\hline Marital stat & & & & \\
\hline Single & 27 & 29.7 & 64 & 70.3 \\
\hline Married & 57 & 31.7 & 123 & 68.3 \\
\hline Nationality & & & & \\
\hline Malaysian & 84 & 31.0 & 187 & 69.0 \\
\hline Educational & & & & \\
\hline High school & 3 & 10.7 & 25 & 89.3 \\
\hline Diploma & 33 & 38.4 & 53 & 61.6 \\
\hline $\mathrm{BSc}$ & 38 & 32.8 & 78 & 67.2 \\
\hline Masters & 8 & 21.6 & 29 & 78.4 \\
\hline $\mathrm{PhD}$ & 2 & 50.0 & 2 & 50.0 \\
\hline Work experi & & & & \\
\hline Below 2 & 9 & 30.0 & 21 & 70.0 \\
\hline $2-5$ & 25 & 23.8 & 80 & 76.2 \\
\hline $6-10$ & 23 & 27.4 & 61 & 72.6 \\
\hline Above 10 & 27 & 51.9 & 25 & 48.1 \\
\hline
\end{tabular}

Dimension

Cronbach's $\alpha$ score

Leadership approaches

Transformational

0.790

Transactional

0.907

Servant-leadership

0.916

Islamic leadership principles

Principles

0.907

Leadership styles, roles and traits

Styles

0.855

Roles

0.877

Traits

0.92

Reliability analysis of

$\begin{array}{ll}\text { Islamic leadership } & \text { Sources of your own leadership } \\ \text { principles } & \text { Followership principles }\end{array}$

0.936

constructs in the study. More tables about reliability test (Cronbach's $\alpha$ ) are shown in Appendix 2.

Factor analysis

Factor analysis, a class of procedures primarily used for data reduction and summarization (Malhotra and Birks, 1999, p. 760), is used to examine discriminant validity. Factor loadings were obtained using SPSS factor analysis procedure in order to create constructs. 
The value of factor loadings indicates the strength of the relationship between the item and the factor. The minimum requirements for the value of factor loadings is 0.3 ; one should take into account all factor loadings with the value above 0.4 as important, while those which have the value above 0.5 are considered significant (Sharma, 1996, p. 111). Therefore, the higher the factor loading, the claim that the item is represented by the factor which is assigned to it, is more reliable.

This research consists of six main factors: leadership approaches (transformational, transactional, and servant-leadership), Islamic leadership principles, leadership styles, leadership roles, leadership traits, and sources of your own leadership (followership principles). The purpose of this section is to explain how the scales for each of the constructs were developed. The following are the value of factor loading of particular items shown in Table III:

- Leadership approaches. This factor consists of three sub-factors which are transformational, transactional, and servant-leadership approaches. Each sub-factor is measured by eight items of question which was included in the questionnaire. Leadership approaches refer to how Islamic leaders influence the Muslim Ummah to follow God's commands. Factor loading scores are presented in Table III. As one can see, all sub-factor loadings of leadership approaches constructs are highly significant (above 0.50). The highest factor loading is the transactional approach which is 0.977 and the lowest factor loading is the servant-leadership approach 0.927 (above 0.50). Therefore, all items formed the leadership approaches.

- Islamic leadership principles. This component consists of eight items of questions included in the questionnaire. This construct measures how Islamic leadership principles influence the Muslim people who are working in the organization. This component factor loading is 0.841 (above 0.50 ) which is highly significant.

- Leadership styles. This factor consists of nine items of questions included in the questionnaire. This construct measures the extent to which leadership styles influence the Muslim employees in the working place. Factor loadings on this factor are presented in Table III, and it can be seen that factor loadings are highly significant (above 0.50).

- Leadership roles. This component consists of nine items of questions included in the survey questionnaire. This construct measures how leadership roles influence Muslim employees' behavior in their workplace. This construct factor loading is 0.832 (above 0.50 ) which indicates this factor loading is highly significant.

- Leadership traits. This factor consists of nine items of question included in the questionnaire. This construct measures which leadership characteristics encourage Muslim employees to follow their organizational leaders in the workplace. It can be seen in Table III that loadings on this factor are highly significant (above 0.50).

- Followership principles. This component consists of nine items of questions included in the questionnaire. This construct measures the extent to which source of leadership influences Muslim employees to follow the Islamic leadership principles in the workplace as well as in their personal life. This construct factor loading is 0.987 (above 0.50 ) which indicates this factor loading is highly significant.

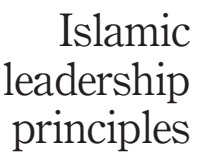

299 
IJCOMA

21,3

300
Table III.

Pearson correlations of Islamic leadership principles

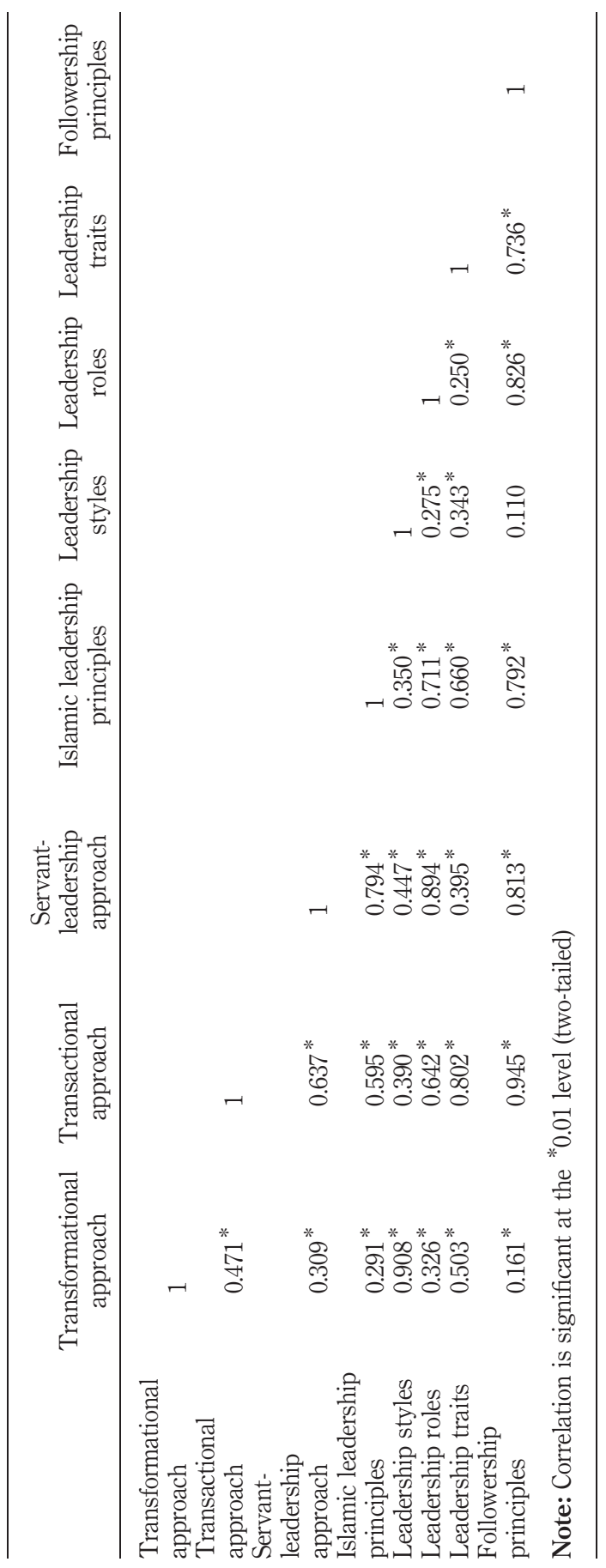


Based on previous reviews of Islamic management and leadership literatures, the researcher developed and tested eight Islamic leadership principles. Respondents were asked to assess these principles in their leaders or supervisors. Analyses of these principles are shown in Figure 1.

Leadership approaches. Respondents were asked to assess eight attributes of transformational qualities in their leaders or supervisors. Analyses of these attitudes are shown in Figure 2.

Respondents were asked to assess eight attributes of transactional qualities in their leaders or supervisors. Analyses follow in Figure 3.

Respondents were asked to assess eight attributes of servant-leadership qualities in their leaders or supervisors. Analyses are shown in Figure 4.

Sources of leadership/followership principles: an analysis. Respondents were asked to identify the sources of their leadership or followership principles in their capacity as either leaders or subordinates. Thus, responses fell either in the category of staff being a leader (middle-line staff) or as a subordinate (first-line staff). Respondents were given the choice to pick among nine sources as shown in Figure 5.

Extent of Islamic influence: an analysis. Figure 6 shows a pie chart of responses on the extent of influence Islam has leadership or followership principles. Respondents were

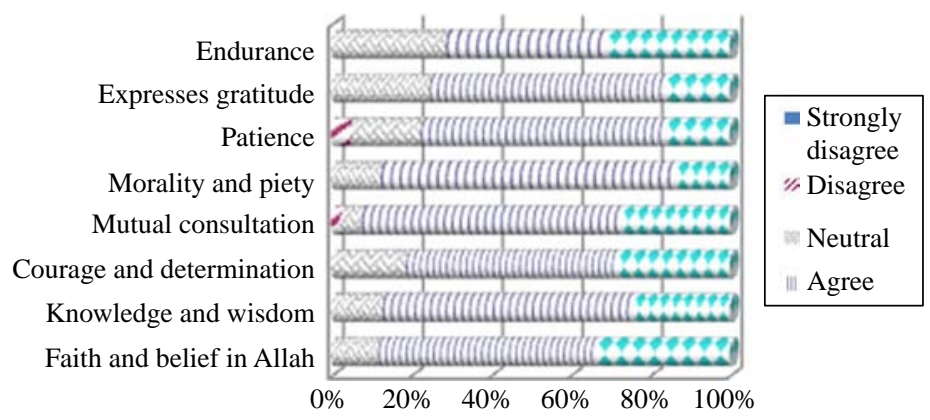

Note: Islamic leadership principles analysis

Source: Field survey

Figure 1.

Responses on Islamic leadership principles
Talks optimistically about the ... Articulates future opportunities Mobilizes a collective mission

Creates awareness of shared ... His trusted to overcome obstacle Loves being associated with Serve as a role model for me Enhances his image of ...

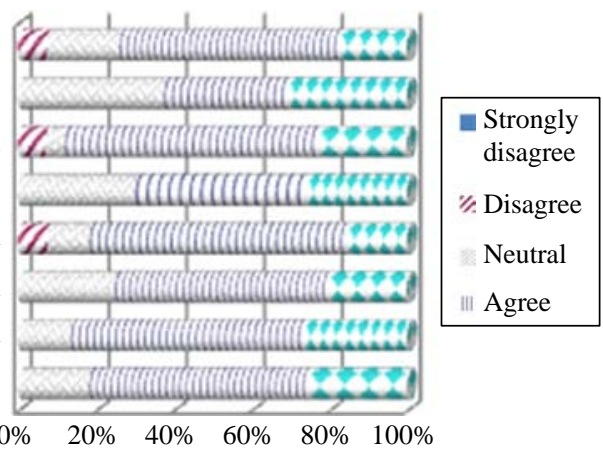

Note: Transformational approach analysis Source: Field survey

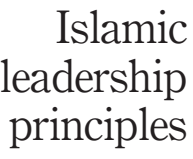

301 


\section{IJCOMA}

21,3

302

Figure 3.

Responses on transactional leadership approach

Figure 4.

Responses on servant-leadership approach

Figure 5.

Responses on sources of leadership/followership principles

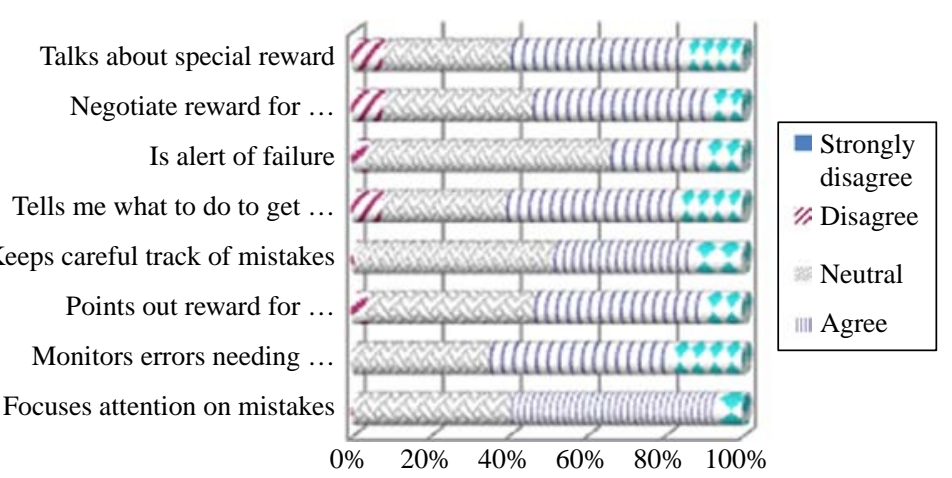

Note: Transactional approach analysis

Source: Field survey

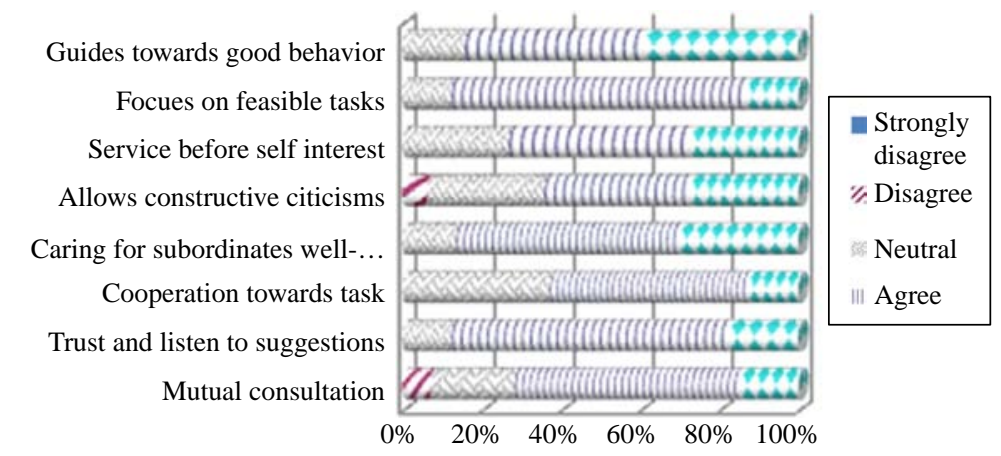

Note: Servant-leadership approach analysis

Source: Field survey

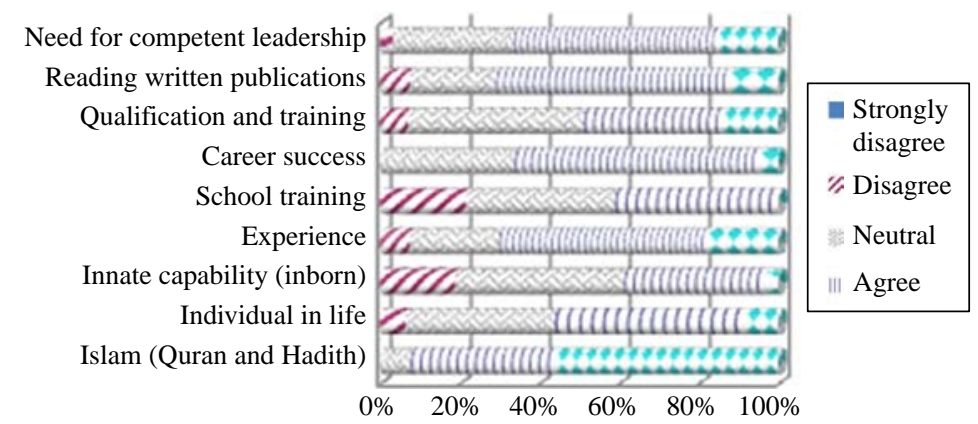

Source: Field survey

asked to indicate the extent to which they are influenced by the revealed sources of knowledge in Islam (Qur'an, Sunnah, and Seerah) in the practice of leadership or followership principles. Approximately 205 (or 75.6 percent) of respondents were strongly influenced by Islam in adhering to leadership or followership principles. 
While an approximate of 59 (or 21.8 percent) expressed mildly influence on this view, less proportion of respondents seven (or 2.6 percent) approximately preferred to be neutral.

\section{Findings-interpretation}

This part consists of findings and interpretation from analyses made above followed by steps taken to provide answers to the research questions underlying this study:

$R Q 1$. Which leadership approach is used within the organizational structure of 303 International Islamic University Malaysia?

The study focused on three leadership approaches. From the analyses above, it was found that the three leadership approaches: transformational, transactional, and servant-leadership were prevalent within the university. However, analyzing the degree at which these approaches supersede each other, we found that academic administrators in the university used most often the servant-leadership approach (Figure 7). The mean score for each approach as shown in Appendix 1 is as follows: 1,078.62 (or approximately 35 percent) for servant-leadership approach, 1,076.50 (or approximately 34 percent) for transformational leadership approach, and 979.25 (or approximately 31 percent) for transactional leadership approach (refer to Appendix 1 for statistical mean):

RQ2. To what sources do the university administrative staffs attribute their use of leadership principles?
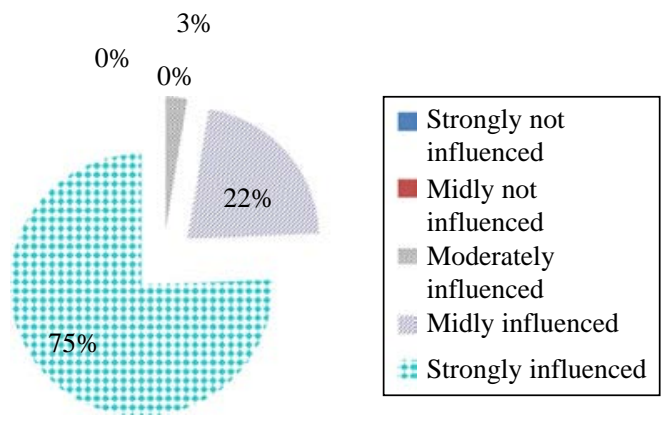

Source: Field survey

Figure 6.

Degree of Islamic influence on leadership/followership principles

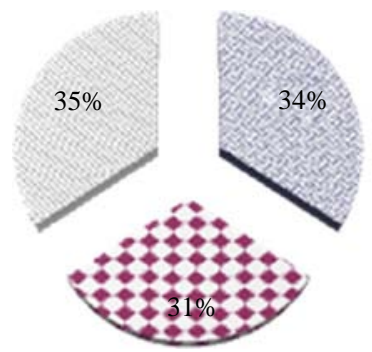

Transformationa

; Transactional

Figure 7.

Source: Field survey 
IJCOMA

21,3

304

With reference to Figure 8, respondents were given nine alternatives to choose from regarding their sources of leadership or followership principles. The researcher calculated the statistical mean score of all responses on the nine sources. Findings revealed that the Islamic revealed sources of knowledge (Qur'an and Hadith) had the highest mean score of 4.4797. Close to this source were: experience 3.8044, need for competent leadership 3.7823, reading literature available through publications 3.7565 , and career success 3.7085 .

Also in the rank were sources from individuals and personality in life 3.5793, qualification 3.5535, and innate capability 3.2325. School training was the least in the rank with a mean score of 3.1956. The researcher concluded that the religion of Islam is the highest source of leadership or followership principles used by members of administrative staff in the university. Refer to Appendix 1 for the statistical mean table of the nine sources of leadership principles:

$R Q 3$. To what degree has Islam influenced the use of the leadership or followership principles?

Few respondents of about seven (or 2.6 percent) chose to be neutral on the degree of influence Islam had on their leadership or followership principles. However, the combination of both mildly influenced and strongly influenced options showed a total of 264 (or 97.4 percent) respondents feel influenced by Islamic tenet (Figure 6; Appendix 1). From this analysis, it can be concluded that the religion of Islam plays an immense role and has a vast influence on the practice of leadership and followership principles in the university.

\section{Islamic leadership principles used by academic administrators}

Respondents were asked to give their opinion on eight Islamic leadership principles shown in Figure 1. However, the researcher took further steps to calculate the statistical mean scores of these principles. This is aimed at revealing their order of preference by respondents (Appendix 1). As shown in Figure 9, the principles of faith and belief in Allah (SWT) was given the highest priority by respondents with a mean

Figure 8.

Mean scores on sources of leadership/followership principles

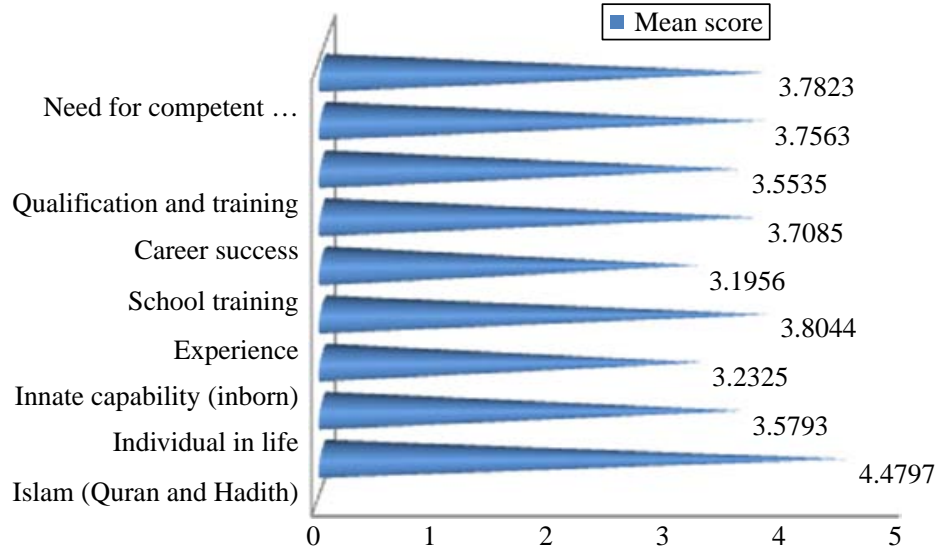

Source: Field survey 


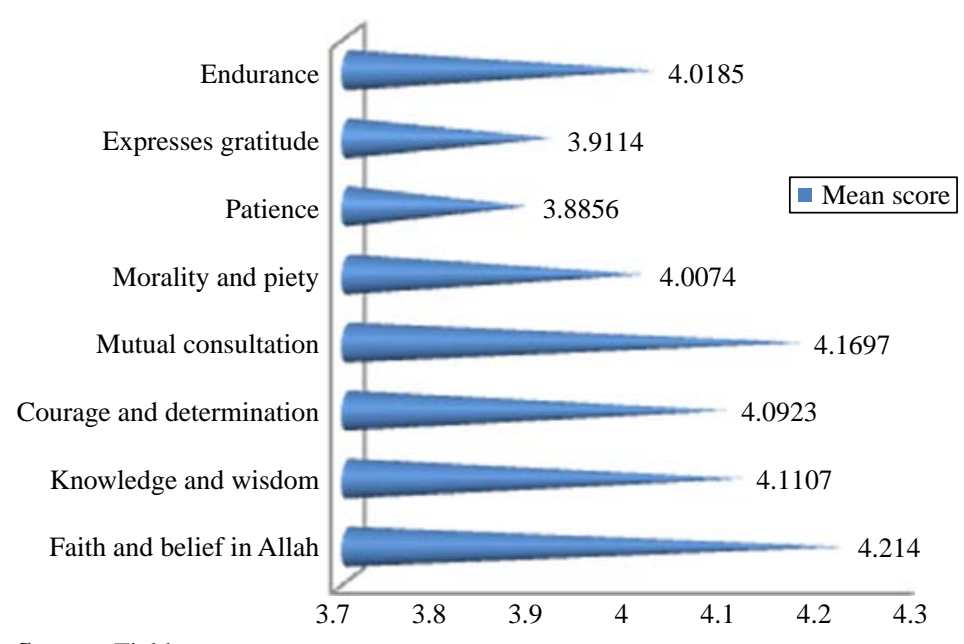

Source: Field survey

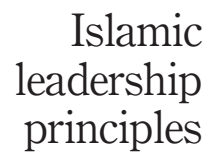

305

Figure 9.

Mean scores on Islamic leadership principles

score of 4.2140. The principles of mutual consultation, knowledge and wisdom were favored next; they had mean score of 4.1697 and 4.1107, respectively. Accordingly, $4.0923,4.0185$, and 4.0074 represented the mean scores of the principles of courage and determination, endurance, morality, and piety.

Both principles of expressing gratitude and patience had a mean score of 3.9114 and 3.8856 , respectively. However, the researcher concurs that all the principles were of equal importance in any leadership situation. This was established in lieu of the closeness in the difference between individual principle mean score calculated.

\section{Relationship of Islamic leadership principles}

Correlation analysis is used to examine the relationship between two variables in a linear fashion. This study used Pearson correlation coefficients to measure the relationship of the independent variables (transformational approach, transactional approach, servant-leadership approach, leadership styles, leadership roles, leadership traits, and followership principles) with the dependant variable (Islamic leadership principles). Cohen (1988) suggested some guidelines as to the strength of the relationship of the variables, whether it is small, medium, or large. The Pearson correlation matrix is shown in Table III.

Based on the data analysis, all independent variables were found to have medium positive relationships with each other. According to Uma and Bougie (2003), if any of the variables have correlations higher than 0.75 , it is suspected that the correlated variables are two different and distinctive variables and would have doubted the validity of the measures, which in this case all variables are valid.

From the Pearson correlations matrix Table III, we can see that correlations among all the variables are positive and significant at 0.001 levels which indicate that all measuring is expressing same underlying characteristics. Generally, all the values of the inter-item correlation matrix should be positive. If there is any negative values in the inter-item correlation matrix, that indicates some of the items have not been correctly reverse scored. 
IJCOMA

21,3

306

\section{Discussion}

In summing up the discussion at the end, we found out that the application of Islamic leadership principles is very much in existence in the International Islamic University Malaysia. This view has been expressed through responses obtained from the survey-based questionnaires. The servant-leadership approach is more dominant in leaders or supervisors in the university. This is not to say that transformational and transactional leadership approaches are neglected. They are used when situations demand that added further value of flexibility to allow leaders to respond to the changing circumstances of environmental and group dynamics.

The Prophet (SAW) did not elicit obedience from his followers simply because of transactional style merely based on generosity towards them or because of his personal and prophetic attributes only. Rather, his approach to leadership was also transformational and servitude to his followers (Beekun, 2006). Bass (as cited in Paronili, et al., 2009) though supported the unique aim of each leadership approach but said that servant-leadership "goes beyond transformational leadership in selecting the needs of others as its highest priority". The present research confirms this empirically.

To help bring about the requisite changes in the Arabian Peninsula at that time, the Prophet (SAW) patiently transformed a desperate group of unimportant communities who were rivals by raising the level of their spiritual being and higher level of thinking on their mutual awareness of selflessness, helping them understand the need for a social change, enable them to transform and move beyond their self-interests, modelling for them the way, and developing a climate of trust, which become the basis for managing a desired change:

You have indeed in the Apostle of Allah a beautiful pattern of conduct for everyone whose hope is in Allah and the Final Day and who engages in the praise of Allah (Surah Azab [33]: 21).

Khaliq (2007a, b) expressed that leadership in Islam is not merely a transactional relationship based on mutual interest between the leader and his followers but is also an unconditional moral relationship enhancing the spiritual and material development of subordinates and the society at large. Prophet Muhammad (SAW) embued with several of the transactional and transformational leadership principles, nevertheless had a unique leadership style that contained elements that extend beyond being a transactional and transformational leader. He practiced a leadership style that rises above some of the potential deficiencies of these two approaches as critics have pointed out today. A more recent Islamic value-based leadership theory that encompasses some of the elements of both transactional and transformational approaches is the servant-leadership approach (Khaliq, 2009; Beekun, 2006). Greenleaf as (cited in Beekun, 2006) explained that the servant-leader focuses on the needs of others rather than his or her own needs encompassing the quality of selflessness found in rare personalities. Covey (as cited in Robert, 2001) wrote that the servant-leadership concept is a principle of a natural law (Fitrah) and that getting our social value systems and personal habits aligned with it is one of the great challenges of our lives.

The fundamental motivation for leadership should be a desire to serve (Robert, 2001). Parolini (as cited in Parolini et al., 2009) concluded that the moral distinction of the servant-leader is his or her conscious sacrificial and altruistic service towards individual followers' highest priority needs. Patterson (as cited in Mihai 
and Robert, 2005) posits that servant-leader leads and serves people with love, acts with humility, is altruistic, visionary for the followers, trusting, serving, and empowers followers. Some principles of servant-leadership approach are also appended at the end of this study. The Prophet (SAW) said:

A ruler who has been entrusted with the affairs of the Muslims, but makes no endeavour (for their material and moral uplift) and is not concerned (for their welfare) will not enter Paradise with them (Sahih Muslim).

A godly leader finds strength by realizing his weakness, authority by being under authority, direction by laying down his own plans, vision by seeing the needs of others, credibility by being an example, loyalty by expressing compassion, honour by being faithful, and greatness by being a servant (Roy, n.d.).

As a summary, this study focused on studying the philosophy of leadership from an Islamic perspective. The study proved that academic administrators in IIUM find more solace with the use of servant-leadership approach, thus humility and respect for others formed the basis of servant-leadership. The approach is imbued with several Islamic leadership principles such as mutual consultation, service before self, care for subordinates' well being, patience, endurance, and ultimately strong faith and belief in Allah. Servant-leaders forfeit personal interest by serving the followers first. They look to their impact of decisions on the least privileged in the society and determine if their service is contributing to a better way of life for the least privileged.

The viewpoint of servant-leadership approach as practiced by Prophet Muhammed (SAW) is that leadership is not seen as a privilege or position. It is rather a huge responsibility. Thus, leaders need to feel as if they are servants in order to be able to fulfil their duties in the best way possible. They share their responsibilities and authority with others to meet a greater need, that is, by involving followers in planning and decision making (Shura). The approach revolves on brotherhood in which the leader and all members of organization are considered part of extended family. Here, leaders tend to feel they are not better than any other person in the organization. Aside from dealing with others exactly as they like to be dealt with, they tend to also act like a guide who is concerned with the followers' well being, they direct them towards understanding the organization's vision and how their followers are going to achieve the vision successfully in their due course of performing duties in the best manner both in mundane life and inshallah (God willing) in the hereafter.

\section{Conclusion/recommendations}

Islam is indeed a comprehensive, integrated, and holistic religion that governs and interweaves with regards to all aspects of life. Duniya (everyday life) and Akhirah (hereafter) do not stand in conflict with each other. So also is operating a business and Ibadah as long as one maintains a strong Iman (faith) hoping to seek Allah's pleasure, the Muslim's ultimate goal in life. Thus, the rule of exception to any leadership is not arising at all; the Islamic leadership is seen as one that assists the individual in attaining happiness in both the worlds. It directs utilizing human resource properly in order to serve society in achieving happiness. It is one that ensures happiness for the individual and society at large.

Islam requires Muslims to conduct their affairs properly either as leaders or subordinates in their respective position. The following are general ways to further
Islamic
leadership
principles

307 
IJCOMA

21,3

\section{8}

improve and create an enabling internal environment for Islamic leadership development in organizations such as educational institutions, private or public sector businesses, hospitals, etc.:

- An organization should be structured around the concept of shura (mutual consultation). It is a concept which employs a system of open participation where all employees make continuous and meaningful input for improvement in running the organization. It is also believed that this promotes the highest degree of efficiency and effectiveness.

- The Islamic-modelled organization should not only cater to the economic needs of employees but should also provide support for their social and spiritual needs. For instance, the observance of congregational prayers at workplace helps to close ranks and create trust and acquaintance with each other resulting into social relationships that extend beyond the work place.

- Principle of Nassiha (descent advice) should be applied by leaders. They should offer sincere advice to subordinates for career advancement while also listening to their suggestions in a manner that truly builds an interactive learning organization.

- The organization is to adopt a fully cooperative style for good governance and forbid the happening of anything bad. This is taken to be not only good work ethics but a religious duty.

- Leaders should be imbued with the aptitude to integrate the rulings and directives in the Qur'an and Hadith with the regulations of the organization. This may enhance mutual and cooperative efforts in cooperative resolution of differences and conflicts among subordinates in a true sense of achieving organizational justice.

- While recruiting employees, justice is to be adopted. Posts are to go to the best qualified individual in accordance to both technical and personal qualifications. This supports effective leadership system as guided by Al-Quran as follows:

One of the two women said: $\mathrm{O}$ my father! Hire him! Verily, the best of men for you to hire is the strong, the trustworthy (Surah Al-Qasas [28] 26).

- The line of authority and responsibility is to be clear and delineated to remove all possible sources of ambiguity. That is, tasks are to be clearly defined so that everyone knows what his or her role is.

- Subordinates are to obey the directives of their leaders as long as those directives are within the prescribed limit of organization rules, are not harmful to anyone, and do not go against guidance and the declarations of Allah and his prophets.

Scope for further research in the area of MIP could include Islamic thought on leading, planning, organizing, controlling, and staffing to moral and ethical issues. The main focus and thrust of this study is empirically testing the leadership from an Islamic perspective. However, further readings on other areas of Islamic management will help to fully integrate our knowledge on Islam and the management of an organization from an Islamic perspective. 
The changing corporate environment in twenty-first century has brought up many unprecedented challenges before corporate leadership which is today eagerly looking for an alternative approach. Leadership from Islamic perspective could offer such an alternative approach. Thus, there arises the need for Muslim management experts to expand their frontier of knowledge to being actively involved in undertaking research on MIP as their contribution to the existing literature and knowledge of contemporary management.

\section{References}

Adnan, A. (2006), "A study of Islamic leadership theory and practice in K-12 Islamic school in Michigan", available at: http://contentdm.lib.byu.edu/ETD/image/etd1273.pdf (accessed 30 January 2009).

Al-Buraey, M.A. (2006), Islamic Principles in the Management of an Organization: A Focus on Leading, King Fahd University, Al-Dharan, available at: http://ocw.kfupm.edu.sa/user062/ MGT30100102/Islamic\%20Princ\%20Focus\%20on\%20Leadership\%20malaysia2003c1. ppt (accessed 27 August 2008).

Ali, J.S. (2007), "Leadership: an Islamic perspective”, paper presented at International Conference, Management from Islamic Perspective at Hilton Kuala Lumpur, 15-16 May, Organized by KENMS.

Arsyianti, L.D. and Beik, I.S. (2007), "Islamic paradigm on leadership and management: a conceptual analysis", paper presented at International Conference, Management from Islamic Perspective at Hilton Kuala Lumpur, 15-16 May, Organized by KENMS.

Beekun, R.I. (2006), Strategic Planning and Implementation for Islamic Organizations, The International School of Islamic Thought, Hernden, VA.

Beekun, R.I. and Badawi, J. (1999), Leadership: An Islamic Perspective, Amana Publications, Beltsville, MD.

Cohen, J. (1988), Statistical Power Analysis for the Behavioral Sciences, 2nd ed., Lawrence Erlbaum, Hillsdale, NJ.

Dewi, M.K. and Tanjung, H. (2007), "Discipline without punishment - is it possible?", paper presented at International Conference, Management from Islamic Perspective at Hilton Kuala Lumpur, 15-16 May, Organized by KENMS.

Emory, C.W. (1985), Business Research Methods, Irwin, Homewood, IL.

Faridi, F.R. (1991), "Islamic research methodology, some reflections”, Journal of Objective Studies, Vol. 3 No. 1, pp. 149-57.

Hossain, M. (2007), "Case studies of Muslim managed organizations in Bangladesh", paper presented at International Conference, Management from Islamic Perspective at Hilton Kuala Lumpur, 15-16 May, Organized by KENMS.

Ismail, Y. (2007), "A proposed approach to the development of Islamic management as a discipline”, paper presented at International Conference, Management from Islamic Perspective at Hilton Kuala Lumpur, 15-16 May, Organized by KENMS.

James, C.S. and Joseph, C.S. (2008), "The transformational-transactional leadership model in practice”, Leadership \& Organization Development Journal, Vol. 22 No. 8, pp. 383-93, available at: Emerald Database (accessed 4 December 2008).

Kazmi, A. (2007), "Managing from Islamic perspectives: some preliminary findings from Malaysian Muslim-managed organizations", paper presented at International Conference, Management from Islamic Perspective at Hilton Kuala Lumpur, 15-16 May, Organized by KENMS.

Khaliq, A. (2003), "Management model from Islamic perspectives: some reflections", Ulum Islamiyyah, No. 1, pp. 43-60. 
IJCOMA

21,3

Khaliq, A. (2007a), "Leadership and work motivation from Islamic perspective", paper presented at International Conference, Management from Islamic Perspective at Hilton Kuala Lumpur, 15-16 May, Organized by KENMS.

Khaliq, A. (2007b), Management from Islamic Perspectives - Principles and Practices, Research Centre, IIUM, Kuala Lumpur.

Khaliq, A. (2009), "Leadership and work motivation from the cross-cultural perspective", International Journal of Commerce \& Management, Vol. 29 No. 1, pp. 72-84, available at: Emerald Database (accessed 20 March 2009).

Khan, A. (2007), "Islamic leadership: a success model for everyone and all times", available at: http://americanchronicle.com/articles/view/33073 (accessed 5 January 2009).

Khan, M.W. (1998), "Prophetic principles of success”, Minaret, September, pp. 8-9, available at: http://makkah.wordpress.com/leadership-and-islam/ (accessed 17 December 2008).

Lukman, T. (1995), The Islamic Polity and Leadership, Baron Production Sdn Bhd, Klang.

Malhotra, N.T. and Birks, D.F. (1999), Marketing Research: An Applied Approach, FT/Prentice-Hall, London.

Mihai, B. and Robert, S.D. (2009), "Development of the servant leadership assessment instrument", Leadership \& Organization Development Journal, Vol. 26 No. 8, pp. 600-15, available at: Emerald Database (accessed 2 April 2009).

Muenjohn, N. (2008), "Leadership theories and concepts: its past and present”, paper presented at SouthEast Asia Regional Conference: Globalization, Innovation, and Leadership at Kuala Lumpur, 4-6 December.

Parolini, J., Patterson, K. and Winston, B. (2009), "Distinguishing between transformational and servant leadership", Leadership \& Organization Development Journal, Vol. 30 No. 3, pp. 274-91, available at: Emerald Database (accessed 7 April 2009).

Robert, F.R. (2009), "The role of values in servant leadership", Leadership \& Organization Development Journal, Vol. 22 No. 2, pp. 76-83, available at: Emerald Database (accessed 2 May 2009).

Roy, L. (2009), Website: http://twu.ca/academics/graduate/leadership/servant-leadership/quotes. html (accessed 10 June 2009).

Sanders, W.B. and Pinhey, T.K. (1983), The Conduct of Social Research, CBS College Publishing, New York, NY.

Sharma, S. (1996), Applied Multivariate Techniques, Wiley, New York, NY.

Simon, J.L. (2003), The Art of Empirical Investigation, Transaction Publisher, Piscataway, NJ.

Toor, S. (2007), “An Islamic leadership theory: exploring the extra dimensions”, paper presented at the International Conference, Management from Islamic Perspective at Hilton Kuala Lumpur, 15-16 May, Organized by KENMS.

Uma, S. and Bougie, R. (2003), Research Methods for Business: A Skill Building Approach, Wiley, New York, NY.

\section{Further reading}

Abdul Hamid, A.S. (2007), "Islamic perspective on management: what we need to know and why”, paper presented at AIM ASIAN Business Conference, Manilla, 1 March.

Ahmad, S.F. (1995), "The ethical responsibility of business: Islamic principles and implication”, in Faridi, F.R. (Ed.), Islamic Principles of Business Organization and Management, Qazi Publishers and Distributors, New Delhi. 
Ahmad, S.F. (2007), "Ethical basis of organizational leadership: an Islamic perspective", paper presented at International Conference, Management from Islamic Perspective at Hilton Kuala Lumpur, 15-16 May, Organized by KENMS.

Amer, S. (2006), "Corporate governance from an Islamic perspective", paper presented at International Conference, Management from Islamic Perspective at Hilton Kuala Lumpur, 15-16 May, Organized by KENMS.

Ather, S.M. and Sobhani, F.A. (2007), "Islamic management in Bangladesh: status, issues and solutions", paper presented at International Conference, Management from Islamic Perspective at Hilton Kuala Lumpur, 15-16 May, Organized by KENMS.

Badruddin, I. and Yusuf, I. (2007), "Leadership prerogatives and the role of advisors in organizational decision-making", paper presented at International Conference, Management from Islamic Perspective at Hilton Kuala Lumpur, 15-16 May, Organized by KENMS.

Bulbul, A. and Loqman, M. (2007), "Convergence and divergence between conventional approach and Islamic approach to management", paper presented at International Conference, Management from Islamic Perspective at Hilton Kuala Lumpur, 15-16 May, Organized by KENMS.

Hanafi, A.A. and Sallam, H. (1995), "Business ethics: an Islamic perspective”, in Faridi, F.R. (Ed.), Islamic Principles of Business Organization and Management, Qazi Publishers and Distributors, New Delhi.

Jabnoun, N. (1994), Basic Concepts of Management in Islam, Institut Kajian Dasar, Kuala Lumpur.

Khaliq, A. and Shamim, A. (1995), "Managerial excellence - an Islamic perspective", Malaysian Management Review, Vol. 29 No. 4, pp. 38-45.

Moursi, M.A. (1995), "Some principles of management in Islam", in Faridi, F.R. (Ed.), Islamic Principles of Business Organization and Management, Qazi Publishers and Distributors, New Delhi.

Mustafa, K.A. (1996), Leadership Dynamism: Instilling Vision for the Future Century, Teraju Dinamik Sdn Bhd, Kuala Lumpur.

Rahman, A.R. (1996), "Administrative responsibility: an Islamic perspective”, The American Journal of Islamic Social Science, Vol. 13 No. 4, pp. 497-517.

Salem, A.K. (2001), Towards an Islamic Foundation of Strategic Business Management, IIUM, Kuala Lumpur.

(The Appendix follows overleaf.)

\begin{abstract}
About the authors
Khaliq Ahmad is Dean of KENMS, IIUM, Gombak, Kuala Lumpur, Malaysia. Khaliq Ahmad is the corresponding author and can be contacted at: khaliqahmad@iium.edu.my

Ogunsola O.K is a MOM student at the IIUM Graduate School of Management, KENMS, Kuala Lumpur.
\end{abstract}

\footnotetext{
To purchase reprints of this article please e-mail: reprints@emeraldinsight.com Or visit our web site for further details: www.emeraldinsight.com/reprints
} 
IJCOMA

21,3

312

Table AI.
Islamic leadership
principles
Appendix 1. Frequency and statistical mean tables on Islamic leadership principles, approaches sources of leadership principles and degree of Islamic influence

\begin{tabular}{lrrrrrrrr}
\hline & \multicolumn{2}{c}{$\begin{array}{c}\text { Faith and belief } \\
\text { in God }\end{array}$} & \multicolumn{2}{c}{$\begin{array}{c}\text { Knowledge and } \\
\text { wisdom }\end{array}$} & \multicolumn{2}{c}{$\begin{array}{c}\text { Courage and } \\
\text { determination }\end{array}$} & \multicolumn{2}{c}{$\begin{array}{c}\text { Mutual } \\
\text { consultation }\end{array}$} \\
& Count & $\%$ & Count & $\%$ & Count & $\%$ & Count & $\%$ \\
\hline Disagree & & & & & & & 6 & 2.2 \\
Neutral & 32 & 11.8 & 35 & 12.9 & 51 & 18.8 & 15 & 5.5 \\
Agree & 149 & 55.0 & 171 & 63.1 & 144 & 53.1 & 177 & 65.3 \\
Strongly agree & 90 & 33.2 & 65 & 24.0 & 76 & 28.0 & 73 & 26.9 \\
\hline
\end{tabular}

Table AII.

Islamic leadership principles cont'd

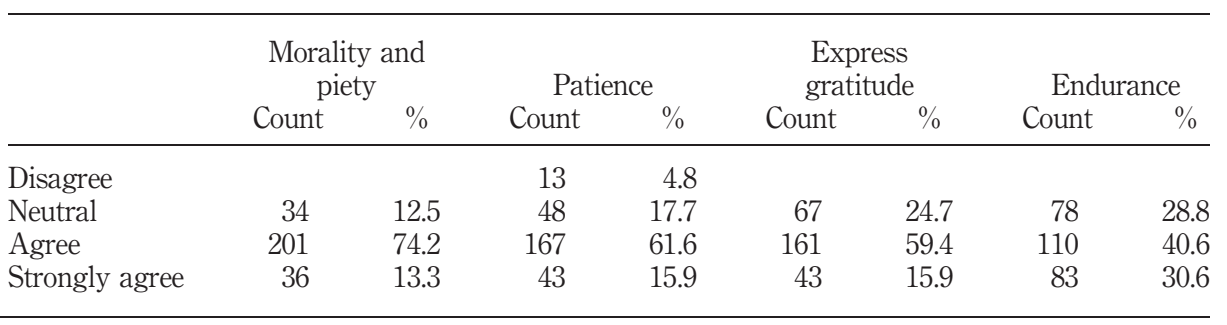

Table AIII.

Transformational leadership approach

\begin{tabular}{|c|c|c|c|c|c|c|c|c|}
\hline & \multicolumn{2}{|c|}{$\begin{array}{l}\text { Enhances his } \\
\text { image of } \\
\text { competence }\end{array}$} & \multicolumn{2}{|c|}{$\begin{array}{l}\text { Serves as role } \\
\text { model for me }\end{array}$} & \multicolumn{2}{|c|}{$\begin{array}{l}\text { Loves being } \\
\text { associated with }\end{array}$} & \multicolumn{2}{|c|}{$\begin{array}{c}\text { Can overcome } \\
\text { obstacles }\end{array}$} \\
\hline & Count & $\%$ & Count & $\%$ & Count & $\%$ & Count & $\%$ \\
\hline Disagree & & & & & & & 20 & 7.4 \\
\hline Neutral & 50 & 18.5 & 37 & 13.7 & 68 & 25.1 & 30 & 11.1 \\
\hline Agree & 153 & 56.5 & 163 & 60.1 & 149 & 55.0 & 180 & 66.4 \\
\hline Strongly agree & 68 & 25.1 & 71 & 26.2 & 54 & 19.9 & 41 & 15.1 \\
\hline
\end{tabular}

Table AIV.

Transformational leadership approach cont'd

\begin{tabular}{|c|c|c|c|c|c|c|c|c|}
\hline & \multicolumn{2}{|c|}{$\begin{array}{c}\text { Creates } \\
\text { awareness of } \\
\text { shared vision }\end{array}$} & \multicolumn{2}{|c|}{$\begin{array}{l}\text { Mobilizes } \\
\text { collective sense } \\
\text { of mission }\end{array}$} & \multicolumn{2}{|c|}{$\begin{array}{c}\text { Articulates } \\
\text { future } \\
\text { opportunities }\end{array}$} & \multicolumn{2}{|c|}{$\begin{array}{l}\text { Talks } \\
\text { optimistic } \\
\text { about the } \\
\text { future }\end{array}$} \\
\hline & Count & $\%$ & Count & $\%$ & Count & $\%$ & Count & $\%$ \\
\hline Disagree & & & 19 & 7.0 & & & 20 & 7.4 \\
\hline Neutral & 82 & 30.3 & 14 & 5.2 & 102 & 37.6 & 51 & 18.8 \\
\hline Agree & 120 & 44.3 & 177 & 65.3 & 87 & 32.1 & 154 & 56.8 \\
\hline Strongly agree & 69 & 25.5 & 61 & 22.5 & 82 & 30.3 & 46 & 17.0 \\
\hline
\end{tabular}




\begin{tabular}{|c|c|c|c|c|c|c|c|c|c|}
\hline & \multicolumn{2}{|c|}{$\begin{array}{l}\text { Focuses on } \\
\text { irregularities } \\
\text { and mistakes }\end{array}$} & \multicolumn{2}{|c|}{$\begin{array}{l}\text { Monitors errors } \\
\text { needing } \\
\text { correction }\end{array}$} & \multicolumn{2}{|c|}{$\begin{array}{l}\text { Point out future } \\
\text { reward for } \\
\text { performance }\end{array}$} & \multicolumn{2}{|c|}{$\begin{array}{l}\text { Keeps track of } \\
\text { mistakes }\end{array}$} & \multirow{2}{*}{ principles } \\
\hline & Count & $\%$ & Count & $\%$ & Count & $\%$ & Count & $\%$ & \\
\hline Disagree & 1 & 0.4 & & & 10 & 3.7 & 2 & 0.7 & \\
\hline Neutral & 110 & 40.6 & 96 & 35.4 & 117 & 43.2 & 139 & 51.3 & Table AV. \\
\hline Agree & 143 & 52.8 & 127 & 46.9 & 119 & 43.9 & 97 & 35.8 & Transactional leadership \\
\hline Strongly agree & 17 & 6.3 & 48 & 17.7 & 25 & 9.2 & 33 & 12.2 & approach \\
\hline
\end{tabular}

\begin{tabular}{|c|c|c|c|c|c|c|c|c|c|}
\hline & \multicolumn{2}{|c|}{$\begin{array}{l}\text { Tells me what } \\
\text { to do get } \\
\text { reward }\end{array}$} & \multicolumn{2}{|c|}{ Alert of failure } & \multicolumn{2}{|c|}{$\begin{array}{l}\text { Negotiate } \\
\text { reward for } \\
\text { performance }\end{array}$} & \multicolumn{2}{|c|}{$\begin{array}{c}\text { Talks } \\
\text { optimistic } \\
\text { about special } \\
\text { reward }\end{array}$} & \\
\hline & Count & $\%$ & Count & $\%$ & Count & $\%$ & Count & $\%$ & \\
\hline Disagree & 21 & 7.7 & 10 & 3.7 & 22 & 8.1 & 22 & 8.1 & \\
\hline Neutral & 87 & 32.1 & 170 & 62.7 & 104 & 38.4 & 89 & 32.8 & Table AVI. \\
\hline Agree & 120 & 44.3 & 66 & 24.4 & 124 & 45.8 & 122 & 45.0 & Transactional leadership \\
\hline Strongly agree & 43 & 15.9 & 25 & 9.2 & 21 & 7.7 & 38 & 14.0 & approach cont'd \\
\hline
\end{tabular}

\begin{tabular}{|c|c|c|c|c|c|c|c|c|c|}
\hline & \multicolumn{2}{|c|}{$\begin{array}{c}\text { Mutual } \\
\text { consultation }\end{array}$} & \multicolumn{2}{|c|}{$\begin{array}{l}\text { Trust and } \\
\text { listens to } \\
\text { suggestions }\end{array}$} & \multicolumn{2}{|c|}{$\begin{array}{l}\text { Cooperation } \\
\text { towards task }\end{array}$} & \multicolumn{2}{|c|}{$\begin{array}{l}\text { Caring for } \\
\text { subordinates }\end{array}$} & \\
\hline & Count & $\%$ & Count & $\%$ & Count & $\%$ & Count & $\%$ & \\
\hline Disagree & 19 & 7.0 & & & & & & & \\
\hline Neutral & 58 & 21.4 & 34 & 12.5 & 101 & 37.3 & 37 & 13.7 & Table AVII. \\
\hline Agree & 155 & 57.2 & 190 & 70.1 & 136 & 50.2 & 153 & 56.5 & Servant-leadership \\
\hline Strongly agree & 39 & 14.4 & 47 & 17.3 & 34 & 12.5 & 81 & 29.9 & approach \\
\hline
\end{tabular}

\begin{tabular}{|c|c|c|c|c|c|c|c|c|c|}
\hline & \multicolumn{2}{|c|}{$\begin{array}{c}\text { Allows } \\
\text { constructive } \\
\text { criticisms }\end{array}$} & \multicolumn{2}{|c|}{$\begin{array}{l}\text { Service before } \\
\text { self-interest }\end{array}$} & \multicolumn{2}{|c|}{$\begin{array}{l}\text { Focus on what } \\
\text { is possible to } \\
\text { accomplish }\end{array}$} & \multicolumn{2}{|c|}{$\begin{array}{l}\text { Guides towards } \\
\text { outstanding } \\
\text { behavior }\end{array}$} & \\
\hline & Count & $\%$ & Count & $\%$ & Count & $\%$ & Count & $\%$ & \\
\hline Disagree & 17 & 6.3 & & & & & & & \\
\hline Neutral & 79 & 29.2 & 73 & 26.9 & 34 & 12.5 & 43 & 15.9 & Table AVIII. \\
\hline Agree & 101 & 37.3 & 125 & 46.1 & 202 & 74.5 & 123 & 45.4 & Servant-leadership \\
\hline Strongly agree & 74 & 27.3 & 73 & 26.9 & 35 & 12.9 & 105 & 38.7 & approach cont'd \\
\hline
\end{tabular}




\section{IJCOMA}

21,3

\begin{tabular}{|c|c|c|c|c|c|c|c|c|c|c|c|}
\hline \multirow[b]{2}{*}{314} & & \multicolumn{2}{|c|}{$\begin{array}{l}\text { Islam (Quran } \\
\text { and Hadith) }\end{array}$} & \multicolumn{2}{|c|}{$\begin{array}{l}\text { Individual in } \\
\text { life (parents, } \\
\text { etc.) }\end{array}$} & \multicolumn{2}{|c|}{$\begin{array}{l}\text { Innate } \\
\text { capability } \\
\text { (inborn) }\end{array}$} & \multicolumn{2}{|c|}{ Experience } & \multicolumn{2}{|c|}{$\begin{array}{c}\text { School } \\
\text { training }\end{array}$} \\
\hline & & Count & $\%$ & Count & $\%$ & Count & $\%$ & Count & $\%$ & Count & $\%$ \\
\hline Table AIX. & Disagree & & & 17 & 6.3 & 51 & 18.8 & 20 & 7.4 & 58 & 21.4 \\
\hline Sources of & Neutral & 21 & 7.7 & 102 & 37.6 & 115 & 42.4 & 61 & 22.5 & 102 & 37.6 \\
\hline leadership/followership & Agree & 99 & 36.5 & 130 & 48.0 & 96 & 35.4 & 142 & 52.4 & 111 & 41.0 \\
\hline principles & Strongly agree & 151 & 55.7 & 22 & 8.1 & 9 & 3.3 & 48 & 17.7 & & \\
\hline
\end{tabular}

Table AX.

Sources of

leadership/followership

principles cont'd

\begin{tabular}{|c|c|c|c|c|c|c|c|c|}
\hline & \multicolumn{2}{|c|}{ Career success } & \multicolumn{2}{|c|}{$\begin{array}{l}\text { Qualification } \\
\text { and training } \\
\text { (seminar) }\end{array}$} & \multicolumn{2}{|c|}{$\begin{array}{l}\text { Reading } \\
\text { written } \\
\text { publication }\end{array}$} & \multicolumn{2}{|c|}{$\begin{array}{c}\text { Need for } \\
\text { competent } \\
\text { leadership }\end{array}$} \\
\hline & Count & $\%$ & Count & $\%$ & Count & $\%$ & Count & $\%$ \\
\hline Disagree & & & 19 & 7.0 & 20 & 7.4 & 9 & 3.3 \\
\hline Neutral & 92 & 33.9 & 120 & 44.3 & 59 & 21.8 & 82 & 30.3 \\
\hline Agree & 166 & 61.3 & 95 & 35.1 & 159 & 58.7 & 139 & 51.3 \\
\hline Strongly agree & 13 & 4.8 & 37 & 13.7 & 33 & 12.2 & 41 & 15.1 \\
\hline
\end{tabular}

Table AXI.

Reliability statistics

\section{Appendix 2}

Leadership approaches

Scale

Cronbach's $\alpha$ Cronbach's $\alpha$ based on standardized items No. of items

Transformational approach

Transactional approach

Servant-leadership

approach

0.790
0.907

0.718

0.908

8

8

0.916

0.917

\section{Islamic leadership principles}

Table AXII.

Reliability statistics (scale: principles)

\begin{tabular}{lcc}
\hline Cronbach's $\alpha$ & Cronbach's $\alpha$ based on standardized items & No. of items \\
\hline 0.907 & 0.907 & 8 \\
\hline
\end{tabular}


Leadership styles, roles, and traits

\section{Islamic leadership principles}

\begin{tabular}{lcccc}
\hline Scale & Cronbach's $\alpha$ & Cronbach's $\alpha$ based on standardized items & No. of items & \\
Leadership styles & 0.855 & 0.855 & 9 & 315 \\
Leadership roles & 0.877 & 0.879 & 9 & \\
Leadership traits & 0.920 & 0.920 & 9 & Table AXIII. \\
\hline
\end{tabular}

Sources of your own leadership

\begin{tabular}{|c|c|c|}
\hline Cronbach's Alpha & $\begin{array}{c}\text { Reliability Statistics } \\
\text { Cronbach's Alpha Based on Standardized Items }\end{array}$ & No. of Items \\
\hline 0.907 & 0.907 & 8 \\
\hline
\end{tabular}

Note: Leadership styles, roles and traits

Table AXIV.

Scale: principles

Factor analysis of Islamic leadership principles

\begin{tabular}{lcc}
\hline & Initial & Extraction \\
\hline Transformational approach & 1.000 & 0.966 \\
Transactional approach & 1.000 & 0.977 \\
Servant-leadership approach & 1.000 & 0.927 \\
Islamic leadership principles & 1.000 & 0.841 \\
Styles & 1.000 & 0.914 \\
Roles & 1.000 & 0.832 \\
Traits & 1.000 & 0.786 \\
Followership principles & 1.000 & 0.987
\end{tabular}

Note: Extraction method: principal component analysis

Table AXV. Communalities

\begin{tabular}{|c|c|c|c|c|c|}
\hline & Frequency & $\%$ & Valid \% & Cumulative \% & \\
\hline Valid & & & & & Table AXVI. \\
\hline Neutral & 7 & 2.6 & 2.6 & 2.6 & Degree of Islamic \\
\hline Mildly influenced & 59 & 21.8 & 21.8 & 24.4 & influence on \\
\hline Strongly influenced & 205 & 75.6 & 75.6 & 100.0 & leadership/followership \\
\hline Total & 271 & 100.0 & 100.0 & & principles \\
\hline
\end{tabular}




\section{IJCOMA \\ 21,3}

316

Table AXVII.

Islamic leadership

principles

\begin{tabular}{lcccc}
\hline & $n$ & Mean & SD & Variance \\
\hline Faith and belief in God & 271 & 4.2140 & 0.63708 & 0.406 \\
Mutual consultation & 271 & 4.1697 & 0.62121 & 0.386 \\
Knowledge and wisdom & 271 & 4.1107 & 0.59839 & 0.358 \\
Courage and determination & 271 & 4.0923 & 0.67958 & 0.462 \\
Endurance & 271 & 4.0185 & 0.77198 & 0.596 \\
Morality and piety & 271 & 4.0074 & 0.50912 & 0.259 \\
Express gratitude & 271 & 3.9114 & 0.63209 & 0.400 \\
Patience & 271 & 3.8856 & 0.71868 & 0.516 \\
Valid $n$ (listwise) & 271 & & &
\end{tabular}

Table AXVIII.

Sources of leadership/followership principles

\begin{tabular}{lcccc}
\hline & $n$ & Mean & SD & Variance \\
\hline Islam (Quran and Hadith) & 271 & 4.4797 & 0.63723 & 0.406 \\
Experience & 271 & 3.8044 & 0.81339 & 0.662 \\
Need for competent leadership & 271 & 3.7823 & 0.73574 & 0.541 \\
Reading written publication & 271 & 3.7565 & 0.75994 & 0.578 \\
Career success & 271 & 3.7085 & 0.55099 & 0.304 \\
Individual in life (parents, etc.) & 271 & 3.5793 & 0.73041 & 0.533 \\
Qualification and training (seminar) & 271 & 3.5535 & 0.81417 & 0.663 \\
Innate capability (inborn) & 271 & 3.2325 & 0.78964 & 0.624 \\
School training & 271 & 3.1956 & 0.76651 & 0.588 \\
Valid $n$ (listwise) & 271 & & & \\
\end{tabular}

Leadership approaches average mean

Transformational approach Transactional approach Servant-leadership approach

Table AXIX. 
IJCOMA

21,3

318

$\underline{318}$

Table AXX.

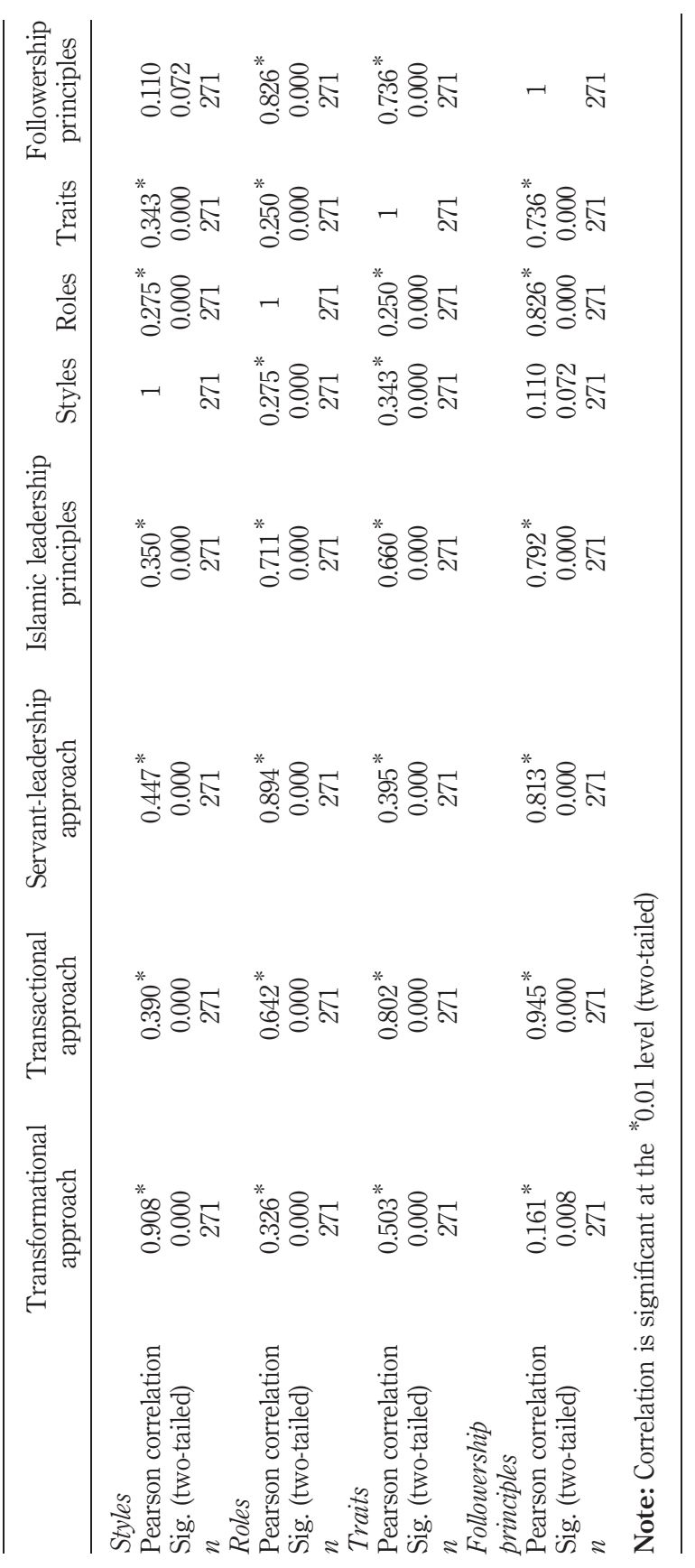

